\title{
Substrate composition and indolebutyric acid on the propagation of Eplingiella fruticosa from cuttings
}

\author{
Anderson de Carvalho Silva ${ }^{1}$ Lenaldo Muniz de Oliveira ${ }^{{ }^{*}}$ Aritana Alves da Silva $^{1}$
}

${ }^{1}$ Unidade Experimental Horto Florestal, Universidade Estadual de Feira de Santana (UEFS), 44020-342, Feira de Santana, BA, Brasil. E-mail: lenaldo.uefs@gmail.com. "Corresponding author.

\begin{abstract}
Eplingiella fruticosa (Salzm. ex Benth.) Harley \& J.F.B. Pastore, also known as "alecrim de vaqueiro" or "cowboy rosemary", is a woody, perennial, and aromatic shrub that growsin the states of northeast Brazil, with the exception of Alagoas, Maranhão, and Piaui. The plant is widely used in this region and has analgesic, vasodilator, anti-inflammatory, and larvicidal properties. The objective of this study was to evaluate the effect of different substrates and indolebutyric acid (IBA) on cuttings of E. fruticosa for identifying effective practices for the vegetative propagation of this species. Apical cuttings with a standardized length of $10 \mathrm{~cm}$ and two pairs of leaves were harvested from mother plants in the vegetative stage. Two experiments were conducted: the first experiment tested the effect of three substrates (commercial, commercial + vermiculite, and commercial + vermiculite + humus $)$ and the second experiment evaluated five concentrations of IBA (0.0, 1.0, 2.0, 3.0, and 4.0 $\left.g L^{-1}\right)$ and three growth periods (30, 45, and 60 days). The experimental design was randomized blocks with four replications. The analyzed variables were survival of cuttings, number of rooted cuttings, root length per cutting (RLC), number of buds per cutting (NBC), leaf dry mass (LDM), root dry mass (RDM), and total dry mass (TDM). In thefirst experiment, there were significant differences in RLC, NBC, $L D M, R D M$, and TDM, with a better growth using the commercial substrate. In the second experiment, there was no interaction between the evaluated parameters. However, there was a positive associated effect of IBA addition and the growth period on RLC, NBC, LDM, and RDM. The highest predicted value was attained for a concentration of $1.5 \mathrm{~g} \mathrm{~L} \mathrm{~L}^{-1} I B A$ and a growth period of 60 days, for the above-mentioned variables. Key words: Lamiaceae, vegetative propagation, medicinal plants, Hyptis.
\end{abstract}

Composição de substrato e ácido indolbutírico na estaquia de "alecrim de vaqueiro"

RESUMO: $O$ "alecrim de vaqueiro" é um arbusto lenhoso, aromático e perene, que ocorre nos estados do nordeste brasileiro, à exceção de Alagoas, Maranhão e Piaui. Muito utilizada na região, apresenta propriedades analgésica, vasodilatadora, anti-inflamatória e larvicida. Esse estudo teve como objetivo avaliar a influência de diferentes substratos e do ácido indolbutírico (AIB) sobre a estaquia de "alecrim de vaqueiro", (Eplingiella fruticosa (Salzm. ex Benth.) Harley \& J.F.B.Pastore), visando identificar praticas mais eficazes para sua propagação. Estacas apicais foram colhidas de plantas matrizes, em estágio vegetativo, e padronizadas em $10 \mathrm{~cm}$, com dois pares de folhas. Foram conduzidos dois experimentos: o primeiro testou o efeito de três substratos (comercial, comercial + vermiculita e comercial + vermiculita + húmus) e o segundo avaliou cinco concentrações de AIB $\left(0 ; 1,0 ; 2,0 ; 3,0\right.$ e 4,0g $\left.L^{-1}\right)$ e três períodos de cultivo (30, 45 e 60 dias). O delineamento foi em blocos casualizados, com quatro repetições. Avaliou-se percentagem de sobrevivência das estacas (\%S), percentagem de estacas enraizadas (\%EE), comprimento da raiz por estaca (CRE), número de brotações por estaca (NBE), massa seca de folhas (MSF), massa seca de raiz (MSR) e massa seca total (MST). No primeiro experimento foram verificadas diferenças significativas para CRE, NBE, MSF, MSR e MST, com melhor desempenho para o substrato comercial. No segundo, não houve interação entre os fatores avaliados, contudo, foram identificados efeitos positivos tanto da adição de AIB, quanto dos tempos de cultivo sobre as variáveis CRE, NBE, MSF e MSR, atingindo incremento máximo com a concentração estimada de $1,5 \mathrm{~g} \mathrm{~L}^{-1}$, aos 60 dias de cultivo.

Palavras-chave: Lamiaceae, propagação vegetativa, plantas medicinais, Hyptis.

\section{INTRODUCTION}

Eplingiella fruticosa (Salzm. ex Benth.) Harley \& J.F.B. Pastore (Lamiaceae), popularly known as "alecrim de vaqueiro" is a perennial shrub and native of northeast Brazil. This aromatic plant has a high medicinal and therapeutic potential and is commonly used as a painkiller. The medicinal properties of its essential oil and other extracts have been tested in rats and show edanalgesic, antiinflammatory, antioxidant, and vasodilator effects (SILVA et al., 2006; SANTOS et al., 2007; ANDRADE et al., 2010; MOREIRA et al., 2010; FRANCO et al., 2011; LIMA et al., 2013). Nevertheless, there are no 
record sons the cultivation of this species. There is an increasing pressure on naturally occurring populations because of the extensive extractivism. Therefore, commercial exploration of the species requires the establishment of clonal gardens and nurseries to increase the production of plants, including seedlings and mother plants, and the supply of raw material.

There is a trend in the conservation of native species, particularly in that of species with pharmacological potential. In this sense, ex situ conservation is one of the strategies used to ensure the preservation of germplasm at risk; however, the application of this model requires the implementation of several actions, including domestication and cultivation of the species (SCHEFFER et al., 1999). In the development of cultivation systems, one of the first challenges is to define a propagation method; this stage is a priority for non-domesticated native species for which there is little agronomic knowledge. Asexual propagation is one of the most appropriate methods for plant multiplication, particularly for seeds with low germination, as is the case with $E$. fruticosa that has a rate of germination of approximately $4 \%$ (FERRAZ et al., 2013).

Use of cuttings has been a suitable form of vegetative propagation because of the low cost and success in obtaining uniform crops, with desirable genetic traits (SILVA et al., 2010). However, lack of ability to form roots is a major constraint in this technique for the production of seedlings and the application of exogenous rooting stimulants often becomes necessary (BIASI \& DESCHAMPS, 2009). Application of auxins, such as indolebutyric acid (IBA), is widely used for this purpose (OLIVEIRA et al., 2011). IBA has a remarkable capacity to stimulate rhizogenesis because of the reduced mobility and photosensitivity and higher chemical stability of the compounds in the plant (BASTOS et al., 2009). However, the concentration of the hormone required for each plant species varies depending on factors such as cutting type, age, and genotype (HARTMANN et al., 2002).

Another important factor in seedling production from cuttings is the type of substrate, where in seedling development may be impaired depending on the chemical composition and physical properties of the substrate (WENDLING et al., 2002). Substrates contain different raw materials and are classified according to their material of origin into vegetable, mineral, or synthetic types (FERRAZ et al., 2005). Peat and mineral vermiculite are the most commonly used substrates (FERRAZ et al., 2005). The composition of commercial substrates is complex and often includes a mixture of ingredients from different sources to provide better physical and chemical conditions for seedling development.

Although, studies on the propagation of $E$. fruticosa are lacking, many studies have investigated the propagation of other Lamiaceae species with respect to the type of substrates, including Ocimum gratissimum L. (BLANK et al., 2003; EHLERT et al., 2004), O. basilicum L. (SILVA et al., 2012a), Mentha arvensis L. (AMARO et al., 2013), and Hyptis suaveolens L. (SILVA et al., 2012b), and with respect to the types and doses of auxins, including in Melissa officinalis L. (SEVIK \& GUNEY, 2013), H. leucocephala Mart. ex Benth. and H. platanifolia Mart. ex Benth. (OLIVEIRA et al., 2011).

The objective of this study was to evaluate the effect of different substrates and doses of IBA at varying growth periods on the survival and rooting of plant cuttings and on the initial bud growth to establish an effective method for the vegetative propagation of E. fruticosa.

\section{MATERIALS AND METHODS}

The experiments were conducted at the Agroforestry Experimental Unit of the Universidade Estadual de Feira de Santana (UEFS), Feira de Santana, Bahia, Brazil, from July 2013 to March 2014. The municipality is located at the coordinates $12^{\circ} 15^{\prime} 24^{\prime \prime} \mathrm{S}$ and $37^{\circ} 57^{\prime} 53^{\prime \prime} \mathrm{W}$, with an average altitude of $230 \mathrm{~m}$, annual rainfall of $900 \mathrm{~mm}$, and average annual temperature of $24^{\circ} \mathrm{C}$ (DINIZ et al., 2008).

Apical cuttings of E. fruticosa were collected from parent plants in the vegetative stage and kept in the Collection of Medicinal and Aromatic Plants of the Agroforestry Unit of UEFS; their exsiccate was then herborized and stored in the herbarium of the same institution (Voucher HUEFS 178230). The cuttings had a standardized length of $10 \mathrm{~cm}$, two pairs of leaves, one pair of buds per cutting and were collected early in the morning. Cuttings were subjected to an initial chemical treatment, in which their bases were immersed in a water solution of the fungicide Derosal $500 \mathrm{SC}$ at $5 \mathrm{mgL}^{-1}$. Subsequently, cuttings were planted in trays of expanded polystyrene containing 200 cells, which were kept in a chamber with intermittent nebulization, with an irrigation interval of $3 \mathrm{~min}$ every 2 h. The fertilizer Forth Flores ${ }^{\circledR}$, NPK (6-18-12 + micronutrients) was applied biweekly at the dosage recommended by the manufacturer.

In the production and development of the seedlings, two experiments were conducted. The 
first experiment evaluated the effect of different types of substrates. In the second experiment, the best substrate was used according to the results of the initial experiment. In the second experiment, the effect of different concentrations of IBA on survival of cuttings, rooting of cuttings, and initial bud growth was tested at three growth periods.

The experimental design of the first trial was randomized blocks with four replications. The experimental unit comprised 50 cuttings, with a total of 200 cuttings per treatment. Each 200-cell tray represented a block, and the treatments were organized in plots that contained one of the following three substrates: commercial $\left(\right.$ Biomix $\left.^{\circledR}\right)$,commercial + vermiculite $(1: 1)$, and commercial + vermiculite + humus $(1: 1: 1)$. Effect of the environment was minimized by changing the position of the trays under nebulization throughout the growth period. Thirty days after planting, the following variables were measured: survival of cuttings (SC) in \%,number of rooted cuttings (RC) in \%, root length of cuttings (RLC) in $\mathrm{cm}$, number of buds per cutting (NBC), leaf dry mass (LDM) in mg, root dry mass (RDM) in $\mathrm{mg}$, and total dry mass (TDM) in mg. Dry mass was obtained by exposing the collected parts to a temperature of $60^{\circ} \mathrm{C}$ in an airflow oven until constant weight; it was measured using a precision digital scale. Root length was determined based on the largest root using a millimeter ruler.

The experimental design of the second trial was randomized blocks with four repetitions, arranged in splitplot. The experimental unit comprised 10 cuttings, with a total of 40 cuttings for each IBA concentration. Each tray formed a block, where the plots were represented by the growth periods $(30,45$, and 60 days) and the subplots were represented by four doses of IBA $\left(1.0,2.0,3.0\right.$, or $\left.4.0 \mathrm{gL}^{-1}\right)$ in addition to the control treatment $\left(0.0 \mathrm{gL}^{-1}\right)$. Before planting, the base of the cuttings was immersed in IBA for $5 \mathrm{~min}$ at the planned doses. For the control treatment, cuttings were immersed in fungicide alone. The evaluated variables and procedures used for recording the measurements were the same as those described in the previous experiment.

The data from the first experiment were subjected to analysis of variance, and the means of the treatments were compared by Tukey's test at a level of significance of $5 \%$. In the second experiment, the variables that were significantly different using the F-test $(\mathrm{P}<0.05)$ and were subjected to regression analysis; their corresponding values and equations were then displayed through graphs. Statistical analyses were performed with the software Sisvar version 5.3 (FERREIRA, 2011).

\section{RESULTS AND DISCUSSION}

In the first experiment although, no significant differences in SC and RC were observed, there were significant differences in RLC, NBC, LDM, and TDM (Table 1). Except for RLC, which had the best development with the use of the commercial substrate + vermiculite, higher means were obtained with the commercial substrate.

These results indicated that despite the low nutritional requirement of Eplingiella fruticosa, as indicated by its natural occurrence in poor and sandy soils of northeast Brazil (HARLEY and PASTORE, 2012), the use of a physically and chemically balanced substrate is beneficial for seedling production. The Biomix $^{\circledR}$ substrate is a commercial product used for the production of vegetable seedlings that comprise spine bark, expanded vermiculite, and an organic compound, with a $\mathrm{pH}$ of 6.2 , water retention capacity of $50 \%$, and dry density of $350 \mathrm{kgm}^{-3}$. These characteristics favor water retention, root penetration, and nutrient supply to the buds. The effect of the addition of vermiculite

Table 1 - Survival of cuttings (SC), number of rooted cuttings (RC), root length of cuttings (RLC), number of buds per cutting (NBC), leaf dry mass (LDM), root dry mass (RDM), and total dry mass (TDM) obtained from Eplingiella fruticosa cuttings, grown in different substrate compositions: commercial $\left(\right.$ Biomix $\left.^{B}\right)(C)$, commercial + vermiculite $(\mathrm{C}+\mathrm{V})$ and commercial + vermiculite + humus $(\mathrm{C}$ $+\mathrm{V}+\mathrm{H})$. Feira de Santana, BA, Brazil, 2017.

\begin{tabular}{lccccccc}
\hline Substrato & SC $(\%)$ & RC $(\%)$ & RLC $(\mathrm{cm})$ & NBC & LDM (mg) & RDM (mg) & TDM (mg) \\
\hline C & $36.50 \mathrm{a}$ & $25.75 \mathrm{a}$ & $3.92 \mathrm{~b}$ & $20.00 \mathrm{a}$ & $47.55 \mathrm{a}$ & $43.55 \mathrm{a}$ & $160.25 \mathrm{a}$ \\
$\mathrm{C}+\mathrm{V}$ & $39.27 \mathrm{a}$ & $25.00 \mathrm{a}$ & $4.59 \mathrm{a}$ & $16.24 \mathrm{~b}$ & $41,40 \mathrm{~b}$ & $47.15 \mathrm{a}$ & $141.50 \mathrm{~b}$ \\
$\mathrm{C}+\mathrm{V}+\mathrm{H}$ & $41.25 \mathrm{a}$ & $20.00 \mathrm{a}$ & $4.20 \mathrm{~b}$ & $16.83 \mathrm{~b}$ & $39.10 \mathrm{~b}$ & $47.10 \mathrm{a}$ & $138.60 \mathrm{~b}$ \\
$\mathrm{CV}(\%)$ & 40.91 & 51.72 & 18.81 & 19.97 & 20.95 & 24.99 \\
\hline
\end{tabular}

${ }^{*}$ Means followed by the same letters in the column do not statistically differ to a $5 \%$ probability of error by the Tukey test. 
on RLC may be related to the higher water retention capacity of this compound, which facilitates better penetration of oxygen and diffusion of the nutrients, thus providing better conditions for root development. This result differs from that reported for Ocimum gratissimum L. (Lamiaceae), the roots of the cuttings of which showed limited growth when treated with vermiculite (SOUSA et al., 2005).

In the second experiment, the analysis of variance did not reveal an interaction between the studied parameters. There was a significant effect of the growth period on RLC and RDM. Furthermore, there was a significant effect of the IBA concentration on NBC and LDM (Figure 1). These results suggested that a 30-day period is insufficient for a satisfactory development of E. fruticosa cuttings because of the slow root growth, and a longer period of rhizogenesis is required to increase the chances of survival of the seedlings after transplantation to the field.
The analyses of RLC (Figure 1C) and RDM (Figure 1D) indicated that a growth period of 60 days facilitated better root development in this species, regardless of the IBA concentration. Moreover, during the growth period, the vegetative growth of the cuttings was not restricted by the small volume of the substrate in the tray cells. This result indicated a dormant growth potential that resulted in better rooting and seedling development as the growth period increased. The trend analysis for the 60-day growth period for RLC indicated a quadratic behavior for the tested IBA concentrations; the longest root length was predicted for the IBA concentration of $2.05 \mathrm{gL}^{-1}$. However, IBA inhibited RDM, and the highest RDM values were obtained for the control treatment at all evaluated growth periods (Figure 1D).

BLANK et al. (2003) evaluated the propagation of Ocimum gratissimum L. and reported that a growth period of 60 days achieved adequate
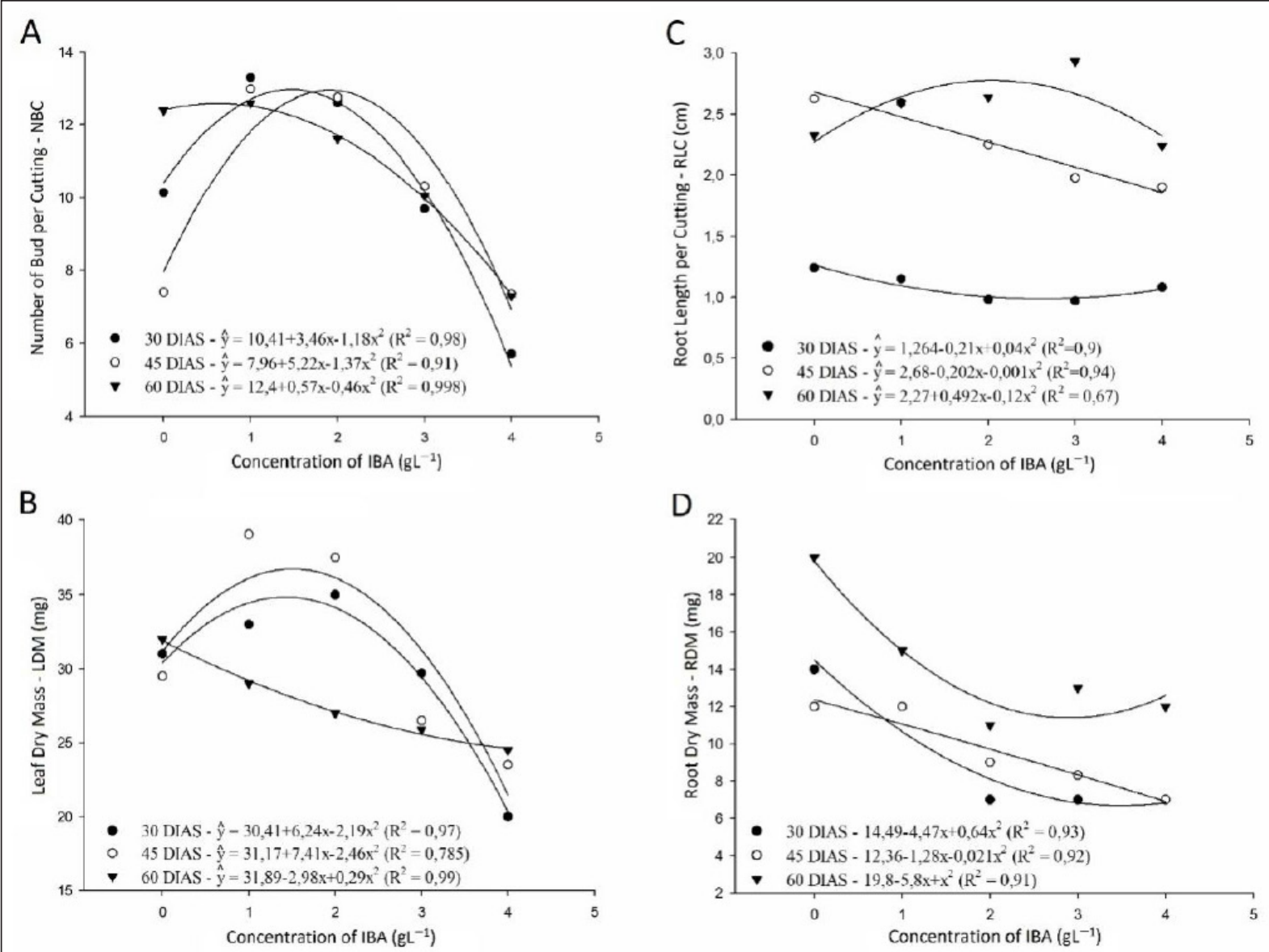

Figure 1 - Number of Buds per Cutting (A); Leaf Dry Mass (B); Root Length per Cutting (C) and Root Dry Mass (D) of Eplingiella fruticosa evaluated in relation to IBA concentration and three growing periods, Feira de Santana, BA, Brazil, 2017.

Ciência Rural, v.47, n.12, 2017. 
development of the seedlings in this species using different types of substrates. BOAVENTURA et al. (2013) reported similar results when evaluating the period required for the formation of seedlings in Lippia alba (Mill.) NE Brown (Verbenaceae), where in periods of 50 and 60 days were observed to promote root development. Nevertheless, these findings differ from those obtained by NETO et al. (2007), who evaluated the initial growth of $H$. pectinata L. (Lamiaceae) for 15, 22, 29, and 36 days, with the best development of seedlings attained at a growth period of 22 and 29 days.

Regression analysis revealed a significant quadratic response of NBC (Figure 1A) and LDM (Figure 1B) to IBA concentrations. There was a considerable increase in NBC in the three growth periods tested, and the predicted maximum was 30 days for $1.5 \mathrm{gL}^{-1}$ of IBA, 45 days for $1.9 \mathrm{gL}^{-1}$ of IBA, and 60 days for $0.7 \mathrm{gL}^{-1}$ of IBA, with a mean increase of 13 buds per cutting. The quadratic response of LDM was similar, with the predicted maximum of 30 days for $1.4 \mathrm{gL}^{-1}$ of IBA and a yield of $37 \mathrm{mg}$ of dry leaves. The effect of the other growth periods on LDM was similar, wherein the predicted higher production of leaf biomass was 45 days for $1.48 \mathrm{gL}^{-1}$ of IBA and 60 days for $1.3 \mathrm{gL}^{-1}$ of IBA. In this study, the mean number of leaves and leaf mass were decreased when the concentration of auxin exceeded the mean concentration of $1.4 \mathrm{gL}^{-1}$; this can be attributed to a possible toxic effect of IBA on E. fruticosa cuttings. It should be noted that varying levels of phytotoxicity were observed in the study period, including yellowish and darkened leaves, leaf and apex rotting, and the formation of callus at the base of the cuttings for all tested IBA concentrations.

OLIVEIRA et al. (2011) observed the positive effect of high concentrations of IBA (1000, 2000 , and $4000 \mathrm{mgL}^{-1}$ ) on the development of cuttings of two Lamiaceae species, Hyptis leucocephala Mart. ex. Benth. and Hyptis platanifolia Mart. ex. Benth. In contrast, SEVIK and GUNEY (2013) evaluated the effect of different hormones on the development of cuttings of Melissa officinalis L. and verified that IBA was not effective in increasing the number of leaf buds. A similar result was reported by CARVALHO et al. (2014), who evaluated the effect of different concentrations of IBA on the development of cuttings of Hyptis pectinata (L.) Poit.

Although, auxins are widely used for root development, they can promote cell division and elongation and stimulate lateral budding depending on the used concentration (DAVIS, 1987). In this study, the cutting of the plant apex, which restricted vertical growth, and the application of synthetic auxin could explain the unexpected lateral budding.

The IBA concentrations used in the present study were effective in increasing the number and growth of new buds by the accumulation of LDM. SILVA et al. (2004) observed that the content of root inhibitory substances of many plants was high in different plant tissues, which might limit their propagation from cuttings. In addition, high concentrations of auxin may lead to an excessive proliferation of cells, intense callosity, and consequent inhibition of roots and shoot growth. Therefore, both conditions may have decreased the development of $E$. fruticosa cuttings because of the low rate of rooting. Nevertheless, the results of this study indicated the potential for the domestication and cultivation of this important medicinal species endemic to Brazil.

\section{CONCLUSION}

Our results suggested that the production of seedlings of $E$. fruticosa by vegetative propagation of apical cuttings is possible. The commercial substrate Biomix ${ }^{\circledR}$ promoted higher bud growth and dry matter accumulation. The 60-day growth period resulted in better root growth. The application of IBA stimulated budding in the cuttings. However, IBA concentrations higher than $1.5 \mathrm{gL}^{-1}$ were detrimental to the development of roots and shoots.

\section{ACKNOWLEDGEMENTS}

The authors are grateful to Conselho Nacional de Desenvolvimento Científico e Tecnológico (CNPq) and Fundação de Apoio à Pesquisa do Estado da Bahia (FAPESB) for all the support in this research.

\section{REFERENCES}

AMARO, H.T.R. et al. Tipos de estacas e substratos na propagação vegetativa da menta (Mentha arvensis L.). Revista Brasileira de Plantas Medicinais, v.15, n.3, p.313-318, 2013. Available from: <http://dx.doi.org/10.1590/S1516-05722013000300001>. Accessed: Oct. 20, 2014. doi: 10.1590/S1516-05722013000300001.

ANDRADE, A.M. et al. Preliminary study on the anti-inflammatory and antioxidant activities of the leave extract of Hyptis fruticosa Salzm. ex Benth., Lamiaceae. Revista Brasileira de Farmacognosia,v.20,n.6,p.962-968,2010. Available from: $<$ http:// dx.doi.org/10.1590/S0102-695X2010005000034>. Accessed: Oct. 20, 2014. doi: 10.1590/S0102-695X2010005000034.

BASTOS, D.C. et al. Estiolamento, incisão na base da estaca e uso do ácido indol-butírico na propagação da caramboleira por estacas lenhosas.Ciências Agrotécnicas, v.33, n.1, p.313318, 2009. Available from: <http://dx.doi.org/10.1590/S141370542009000100043>. Accessed: Oct. 21, 2014. doi: 10.1590/ S1413-70542009000100043. 
BIASI, L.A.; DESCHAMPS, C.Plantas aromáticas: do cultivo à produção de óleo essencial. Curitiba: Layer Studio Gráfico e Editora, 2009. 106p.

BLANK, A.F. et al. Efeitos de composições de substratos na produção de mudas de quiôiô (Ocimum gratissimum L.). Revista Ciência Agronômica, v.34, n.1, p.5-8, 2003. Available from: <http://www.ccarevista.ufc.br/site/artigos_lista. php?sel=2003\&sel2=1\&sel3=34>. Accessed: Oct. 20, 2014.

BOAVENTURA, A.C. et al. Tempo para formação de mudas de erva cidreira a partir da imersão de estacas em água. Cadernos de Agroecologia, v.8, n.2, p.1-5, 2013.

CARVALHO, J.S.B. et al. Effects of the indolbutiric acid in the apical stakes of Hyptis pectinata (L.) Poit. Journal of Global Biosciences, v.3, n.2, p.484-487, 2014.

DAVIS, P.J. The plant hormones: their nature, occurrence, and functions. In: PLANT hormones and their role in plant growth and development. Dordrecht: Kluver Academic, 1987. p.1-11.

DINIZ, A.F.et al. Avaliação dos riscos de seca para o município de Feira de Santana- BA associado à influência do el niño no semi-árido do nordeste brasileiro.+Geografia's, v.1, n.1, p. $18-24,2008$.

EHLERT, P.A.D. et al. Propagação vegetativa da alfavaca-cravo utilizando diferentes tipos de estacas e substratos. Horticultura Brasileira, v.22, n.1, p.10-13, 2004. Available from: <http:// dx.doi.org/10.1590/S0102-05362004000100002>. Accessed: Oct. 20, 2014. doi: 10.1590/S0102-05362004000100002.

FERRAZ, M. et al. Teste de germinação de Hyptis leucocephala e Eplingiella fruticosa (Lamiaceae) para formação do banco de sementes na Unidade Experimental Horto Florestal - Universidade Estadual de Feira de Santana. Magistra, v.25, n. esp., IRGVNE, p.422-423, 2013.

FERRAZ, M.V.et al. Caracterização física e química de alguns substratos comerciais. Acta Scientiarum: Agronomy, v.27, n.2, p.209-214, 2005. Available from: <http://dx.doi.org/10.4025/ actasciagron.v27i2.1483>. Accessed: Aug. 29, 2015. doi: 10.4025/ actasciagron.v27i2.1483.

FERREIRA, D.F. Sisvar: a computer statistical analysis system. Ciência e Agrotecnologia, v.35, n.6, p.1039-1042, 2011. Available from: <http://dx.doi.org/10.1590/S141370542011000600001>. Accessed: Nov. 02, 2014. doi: 10.1590/ S1413-70542011000600001.

FRANCO, C.M. et al. Bioassay-guided evaluation of antinociceptive properties and chemical variability of the essential oil of Hyptis fruticosa. Phytotherapy Research, v.25, p.16931699, 2011. Available from: <http://dx.doi.org/10.1002/ptr.3455>. Accessed: Oct. 22, 2014. doi: 10.1002/ptr.3455.

HARLEY, R.M.; PASTORE, J.F.B. A generic revision and new combinations in the Hyptidinae (Lamiaceae), based on molecular and morphological evidence. Phytotaxa, v.58, p.1-55, 2012.

HARTMANN, H.T. et al. Plant propagation: principles and practices. 7.ed. New Jersey: Prentice Hall, 2002. 880p.
LIMA, A.C.B.et al. Orofacial antinociceptive effect and antioxidant properties of the hydroethanol extract of Hyptis fruticosa Salmz ex. Benth. Journal of Ethnopharmacology, v.146, p.192-197, 2013. Available from: <http://dx.doi.org/10.1016/j.jep.2012.12.031>. Accessed: Oct. 21, 2014. doi: 10.1016/j.jep.2012.12.031.

MOREIRA, I.J.A. et al.Vasorelaxant effect of Hyptis fruticosa Salzm. ex Benth., Lamiaceae, dichloromethane extract on rat mesenteric artery. Revista Brasileira de Farmacognosia, v.20, n.5, p.762-766, 2010. Available from: <http://dx.doi.org/10.1590/ S0102-695X2010005000003>. Accessed: Oct. 21, 2014. doi: 10.1590/S0102-695X2010005000003.

OLIVEIRA, L.M. et al. Propagação vegetativa de Hyptis leucocephala Mart. ex Benth. E. Hyptis platanifolia Mart. ex Benth. (Lamiaceae). Revista Brasileira de Plantas Medicinais, v.13, n.1, p.73-78, 2011. Available from: <http://dx.doi.org/10.1590/S151605722011000100011>. Accessed: Oct. 10, 2014. doi: 10.1590/ S1516-05722011000100011.

SEVIK, H.; GUNEY, K. Effects of IAA, IBA, NAA, and GA3 on rooting and morphological features of Melissa officinalis L. stem cuttings. Scientific World Journal, v.2013, Art.909507, 5p. 2013. Available from: <http://dx.doi.org/10.1155/2013/909507>. Accessed: Oct. 23, 2014. doi: 10.1155/2013/909507.

SCHEFFER, M.C.et al. Conservação de recursos genéticos de plantas medicinais.In: QUEIRÓZ, M.A. et al. (Ed.). Recursos genéticos e melhoramento de plantas para o Nordeste brasileiro. Petrolina: Embrapa Semi-Arido, 1999. V.1, p.1-25.

SILVA, A.B.L. et al. Avaliação do efeito antinociceptivo e da toxidade aguda do extrato aquoso da Hyptis fruticosa Salzm. Ex Benth. Revista Brasileira de Farmacognosia, v.16, n.4, p.475479, 2006. Available from: <http://dx.doi.org/10.1590/S0102695X2006000400006>. Accessed: Oct. 23, 2014. doi: 10.1590/ S0102-695X2006000400006.

SILVA, I.M. et al. Enraizamento de manjericão em diferentes substratos e doses de cinzas. Revista Brasileira de Plantas Medicinais, v.14, n. esp.,p.188-191,2012a. Available from: $<$ http:// dx.doi.org/10.1590/s1516-05722012000500011>. Accessed: Oct. 25, 2014. doi: 10.1590/s1516-05722012000500011.

SILVA, J.M.M. et al. Indução de enraizamento em estacas de joão-brandinho (Piper sp.) com ácido indolbutírico. Ciência Agronômica, v.35, p. 248-252, 2004.

SILVA, P.N.L. et al. Enraizamento de estacas de aceroleira: efeitos de recipientes e substratos. Agrarian, v.3, n.8, p.126-132, 2010.

SILVA, R.C.P. et al. Efeito da composição de substratos no enraizamento de estacas de Hyptis suaveolens (L.) Poit. Revista Brasileira de Ciências Agrárias, v.7, n.2, p. 219-225, 2012b. Available from: <http://dx.doi.org/10.5039/agraria.v7i2a1245>. Accessed: Oct. 16, 2014. doi: 10.5039/agraria.v7i2a1245.

SOUSA, P.B.L. et al. Propagação vegetativa de Ocimum gratissimum L. em diferentes substratos. Revista Brasileira de Plantas Medicinais, v.8, n.1, p.39-44, 2005.

WENDLING, I. et al. Substratos, adubação e irrigação na produção de mudas. Viçosa: Aprenda Fácil Editora, 2002. 165p. 